\title{
GPs' opinions on the NHS and HPA response to the first wave of the influenza $\mathrm{A} / \mathrm{H} 1 \mathrm{~N} 1 \mathrm{v}$ pandemic
}

\author{
Michael Caley, Khesh Sidhu and Rashmi Shukla
}

\author{
ABSTRACT \\ The first wave of influenza $A / H 1 N 1 v$ resulted in a \\ significant demand on primary care services. This \\ cross-sectional study describes GPs' opinions of how \\ information was communicated to them during this \\ period and the overall response of the NHS and Health \\ Protection Agency. Accessibility of current guidance \\ and ease of obtaining antiviral medication were \\ perceived as strengths, but clarity of the information \\ provided was consistently perceived as poor. The \\ majority of GPs supported the introduction of the \\ National Pandemic Flu Service, although many raised \\ concerns about its safety. \\ Keywords \\ health care; influenza; pandemic.
}

M Caley, MPH, MRCP, MFPH, DTMß $H$, specialist registrar in public health; $K$ Sidhu, BSc(Hons), MBA, FFPHM, consultant in public health medicine; $R$ Shukla, FRCP, FFPHM, CBE, regional director of public health, NHS West Midlands, Birmingham.

Address for correspondence

Dr Michael Caley, NHS Birmingham East and North, 3rd Floor, Waterlinks House, Richard Street, Aston, Birmingham B7 4AA. E-mail: Michael.Caley@benpct.nhs.uk Submitted: 27 October 2009; Editor's response: 5 January 2010; final acceptance: 14 January 2010.

@British Journal of General Practice 2010; 60: 283-285.

DOI: 10.3399/bjgp10X483968

\section{INTRODUCTION}

The UK's first wave of the influenza $A / H 1 N 1 v$ pandemic occurred between May and August 2009. As knowledge about this novel virus developed, the guidance for clinicians and the wider health service response changed frequently during this period. The aims of this cross-sectional study are to assess GPs' opinions of the information and advice provided by the $\mathrm{NHS}$ and Health Protection Agency (HPA) during the first wave of $\mathrm{A} / \mathrm{H} 1 \mathrm{~N} 1 \mathrm{v}$, including opinions on the National Pandemic Flu Service (NPFS) and how information dissemination and response could be improved during future periods of significant demand on primary care services.

\section{METHODS}

A random sample of 1002 (35.7\%) of the 2806 GPs in the West Midlands was taken. Each GP was sent a questionnaire in August 2009 asking them about their opinion of communication from the NHS and HPA to primary care, and of the NPFS for the period May 2009 to August 2009. All responses were anonymised.

The questionnaire was designed by public-health staff at NHS West Midlands and aimed to capture the level of satisfaction by using a 5-point scale (from 1 $=$ strongly disagree to $5=$ strongly agree) in response to statements posed. The questionnaire also included free-text questions to capture particular concerns as well as suggestions regarding improving the response to the pandemic.

\section{RESULTS}

Of those who were contacted, 367 (36.6\%) responded, representing $13.1 \%$ of all GPs in the West Midlands. The proportion of GPs who responded in each of the 17 primary care trusts in the region did not differ significantly.

An outline of the items in the questionnaire, together with the GPs' responses, is given in Table 1. Questions specifically looking at the different facets of information provided by the NHS and the HPA showed no significant difference between the two organisations on any criteria. However, the mean scores for clarity of information provided by both the 


\section{How this fits in}

Influenza H1N1v was the first test of the UK's pandemic flu preparedness.

Critically assessing and remembering the lessons learnt from each aspect of the

health sector's response will be essential in ensuring that future threats from

influenza and other emerging infectious agents can be dealt with in the most

effective manner. Clarity of communication and early consultation with GPs are

two areas that need to be developed in order to allow primary care services to

act with as much confidence as possible during periods of uncertainty.

NHS and HPA were significantly lower $(P=0.0002$ and 0.004 respectively [t-test]) than the scores given for the other criteria. This result is corroborated by the statement that advice regarding the management of people with symptoms of swine flu was clear; $61 \%$ of responders disagreed with this. However, $65 \%$ agreed or strongly agreed that they were familiar with latest guidance, which suggests that accessibility to the advice was satisfactory.

Some $79 \%$ of responders agreed or strongly agreed that local arrangements for obtaining antiviral medication were clear, although the means of obtaining personal protective equipment (PPE) was significantly less clear $(P<0.0001[t$-test $])$.

\section{Table 1. Scores for each questionnaire statement.}

\begin{tabular}{|c|c|c|c|c|}
\hline Statement & Mean score & $\begin{array}{l}\% \text { Disagree or } \\
\text { strongly disagree }\end{array}$ & $\begin{array}{l}\% \text { Neither agree } \\
\text { nor disagree }\end{array}$ & $\begin{array}{l}\% \text { Agree or } \\
\text { strongly agree }\end{array}$ \\
\hline $\begin{array}{l}\text { At some time in the last } 3 \text { months your practice has seen a substantial } \\
\text { increase in demand for consultations/enquiries related to flu }\end{array}$ & 4.63 & 3 & 2 & 95 \\
\hline $\begin{array}{l}\text { At some time in the last } 3 \text { months your practice has had to divert } \\
\text { significant resources away from usual business to cope with increased } \\
\text { demands related to flu }\end{array}$ & 3.92 & 15 & 12 & 73 \\
\hline $\begin{array}{l}\text { You are clear about the local arrangements for where and how patients } \\
\text { can obtain antiviral medicines }\end{array}$ & 3.87 & 13 & 8 & 79 \\
\hline $\begin{array}{l}\text { You are clear about the local arrangements for obtaining personal } \\
\text { protective equipment for staff }\end{array}$ & 2.81 & 44 & 21 & 35 \\
\hline You feel well supported by the PCT to respond to this pandemic & 3.01 & 30 & 34 & 36 \\
\hline $\begin{array}{l}\text { The PCT has responded effectively to your concerns about swine flu } \\
\text { and the current NHS response }\end{array}$ & 3.04 & 27 & 38 & 35 \\
\hline $\begin{array}{l}\text { You feel that the level of advice about how to minimise the risk of } \\
\text { infection to you and your staff is sufficient for your practice }\end{array}$ & 3.38 & 20 & 23 & 57 \\
\hline $\begin{array}{l}\text { You were engaged in the planning for a flu pandemic within the } \\
\text { local health economy }\end{array}$ & 2.83 & 40 & 28 & 33 \\
\hline $\begin{array}{l}\text { The advice published by the NHS or HPA regarding the management } \\
\text { of people with swine flu was always clear and not conflicting }\end{array}$ & 2.43 & 61 & 19 & 21 \\
\hline $\begin{array}{l}\text { You feel that the introduction of the NPFS has significantly reduced } \\
\text { the demand on your practice related to flu }\end{array}$ & 3.81 & 11 & 14 & 75 \\
\hline $\begin{array}{l}\text { You feel that the introduction of the NPFS was necessary to allow } \\
\text { primary care services to continue with business as usual }\end{array}$ & 3.84 & 14 & 13 & 74 \\
\hline $\begin{array}{l}\text { You feel that the NPFS can safely assess and provide treatment } \\
\text { for people with flu-like symptoms }\end{array}$ & 2.53 & 50 & 31 & 19 \\
\hline \multicolumn{5}{|l|}{$\begin{array}{l}\text { The information you have received regarding swine flu from your PCT } \\
\text { or the SHA has been: }\end{array}$} \\
\hline - Comprehensive & 3.48 & 17 & 25 & 58 \\
\hline - Clear & 3.11 & 31 & 27 & 42 \\
\hline - Relevant & 3.56 & 13 & 26 & 60 \\
\hline - Easily available & 3.61 & 13 & 25 & 62 \\
\hline \multicolumn{5}{|l|}{$\begin{array}{l}\text { The information that you have received from the HPA about swine flu } \\
\text { has been: }\end{array}$} \\
\hline - Timely & 3.37 & 20 & 28 & 52 \\
\hline - Comprehensive & 3.45 & 17 & 28 & 54 \\
\hline - Clear & 3.14 & 29 & 29 & 42 \\
\hline - Relevant & 3.46 & 17 & 28 & 55 \\
\hline - Easily available & 3.53 & 14 & 30 & 57 \\
\hline
\end{tabular}

HPA = Health Protection Agency. NPFS = National Pandemic Flu Service. PCT = primary care trust; SHA = strategic health authority 
By far the most common free-text suggestions for improvements in response (45\% of all comments) related to reducing duplication and improving the clarity of the information provided. More specific points highlighted that the same information was often sent from primary care trusts, the Royal College of General Practitioners (RCGP) and the HPA, as well as being available on websites. Many comments stated that there were also frequent changes in guidance for reasons considered to be minor or trivial, which made keeping up to date with advice difficult; as did lengthy emails that failed to highlight key issues. There were repeated suggestions for a single authoritative source of information to limit contradictions and duplications.

A further $20 \%$ of comments related to the NPFS, with frequent references being given to concerns about diagnostic ability and prescribing safety of the self-administered and novel clinical algorithm that was used to assess and assign treatment to patients. Some $14 \%$ of comments suggested that the whole response to the pandemic was an overreaction and overhyped by the media.

\section{DISCUSSION}

Responders considered that the NHS and HPA response to the first wave of the pandemic had both strengths and weaknesses. Strengths included the familiarity with, and accessibility of, current guidance on the management of people with symptoms of influenza, as well as the ability to obtain antivirals and infection-control advice. Clarity in the information that was provided consistently scored poorly however, and triangulation with free-text comments reinforces that unclear, duplicated, and conflicting information was one of the areas of greatest weakness, as perceived by the GPs surveyed.

The similarity between the scores for information circulated by the NHS and the HPA suggest that neither organisation's guidance was considered optimal by responders. Methods for obtaining PPE and the engagement of GPs in planning for a pandemic were also highlighted as areas of dissatisfaction.

The strong support for the introduction of the NPFS perhaps highlights the intense pressure that some practices experienced during the first-wave response and its effectiveness in reducing demand for consultations as perceived by GPs. Support may also be reflected in activity figures for influenza-like consultations in primary care in the week following its introduction. ${ }^{1}$ Despite this, reservations were expressed about the safety of the NPFS. Any future deployment of an NPFS-type model to deliver mass assessment and treatment should ensure that high levels of consultation are conducted with GPs to give reassurance about the safety of such a system.

The major limitation of this study is the low response rate. A response rate of over $50-60 \%$ is broadly accepted as the level at which the results can start to be generalised. ${ }^{2}$ As such, it is impossible to generalise these results more widely or draw firm conclusions about the perceived quality of the NHS and HPA response.

There is also the possibility of response bias; people with less-positive experiences are generally expected to be more likely to respond to this type of survey than others. Therefore, it is possible that the whole GP population may have more positive opinions of the first wave than the responding sample but, without conducting a sample of nonresponders, this is impossible to quantify.

The responders were, however, representative in terms of their geographical dispersion across the West Midlands and, as such, the level of demand caused by the pandemic in these different areas. This reduces the chance of geographical response bias.

The aim of this study was not to create precise scores for different areas of the response to the pandemic but to highlight areas of performance that could be improved for the future. Despite the limitations described, this is the only published study of GPs' opinions on this topic and will be useful in forming part of a broader assessment of how the NHS and HPA communicated during this pandemic. These results suggest that a particular focus of any assessment should include how the NHS, HPA, and RCGP could disseminate information regarding pandemic influenza, or any other major health threat, in a more coordinated fashion to prevent GPs from being overwhelmed and confused with duplicated and/or contradictory information.

\section{Competing interests}

The authors have stated that there are none.

\section{Acknowledgements}

The authors wish to acknowledge the work of lan Baker in the administration of this study.

\section{Discuss this article}

Contribute and read comments about this article on the Discussion Forum: http://www.rcgp.org.uk/bjgp-discuss

\section{REFERENCES}

1. Health Protection Agency. HPA weekly national influenza report: 30 July 2009 (week 31). London: Health Protection Agency, 2009.

2. Hager MA, Wilson S, Pollak TH, Rooney PM. Response rates for mail surveys of nonprofit organizations: a review and empirical test. Nonprofit and Voluntary Sector Quarterly 2003; 32(2): 252-267. http://nccsdataweb.urban.org/kbfiles/464/response $\%$ 20rates\%20NVSQ.pdf (accessed 18 Jan 2010). 